\title{
Pilot Underground Greenhouse as an alternative against frequent and intense frosts that occur in the Hidalguense Highlands
}

\section{Invernadero Subterráneo Piloto como alternativa contra las heladas frecuentes e intensas que ocurren en el Altiplano Hidalguense}

\author{
AHUMADA-MEDINA, Albino*†, CHIO-AUSTRIA, Rosa María and AHUMADA-GÓMEZ, Jorge \\ Universidad Politécnica de Pachuca. Pachuca-Cd. Sahagún, Km 20.Rancho Luna. Former Hacienda of Santa Barbara. \\ Zempoala, Hidalgo. México. C. P. 43830 \\ Instituto Tecnológico Latinoamericano. Pachuca, Hidalgo. Pachuca-Cd. Sahagun, Km. 11. Pachuca, Hidalgo. México. C. \\ P. 42083
}

ID $1^{\text {st }}$ Author: Albino, Ahumada-Medina / ORC ID: 0000-0003-3429-1144, Researcher ID Thomson: V-5798-2018

ID $1^{\text {st }}$ Coauthor: Rosa María, Chio-Austria / ORC ID: 0000-0003-2354-073

ID $2^{\text {nd }}$ Coauthor: Jorge, Ahumada-Gómez / ORC ID: 0000-0002-1376-0346

DOI: $10.35429 /$ EJRN.2019.8.5.1.5

Received January 28, 2019; Accepted March 30, 2019

\begin{abstract}
The prevailing weather conditions in the Valles Altos of the Mexican state of Hidalgo enhance high frequency of frosts that usually last from September to April, causing serious damage and constraints on agricultural cycles, both open sky and protected agriculture. In this paper, the results of observations of the behavior of temperatures during night and early morning hours of an underground greenhouse built on the campus of the Polytechnic University of Pachuca are reported. These data allow for an innovative approach to the production of horticultural, ornamental and medicinal plants during the period of frost. After four years of continuous experimentation, there have been cultivated horticultural, ornamental and medicinal plants, during all months of the year, even when they came to present -10 degrees Celsius or lower coolings. As observed, one can conclude that the results have been satisfactory to the experimental design and, therefore, may try to build greenhouses of 2000 square meters with trade capacity throughout the year with some adaptations derived from a larger area.
\end{abstract}

Agricultural damage due to frost, Mexican high plateau frost, Underground greenhouse

\begin{abstract}
Resumen
Las condiciones climatológicas prevalecientes en los Valles Altos del estado mexicano de Hidalgo favorecen una alta frecuencia de heladas que suelen prolongarse de septiembre a abril, lo que ocasiona serios daños y limitaciones en los ciclos agrícolas, tanto a cielo abierto como en la agricultura protegida. En el presente trabajo, se reportan los resultados de observaciones del comportamiento de temperaturas durante noches y primeras horas del día de un invernadero subterráneo construido en el campus de la Universidad Politécnica de Pachuca. Estos datos permiten hacer una propuesta innovadora para la producción de plantas de interés hortícola, ornamental y medicinal durante la etapa de heladas. Tras cuatro años de experimentación continua, se han logrado cultivos de plantas hortícolas, ornamentales y medicinales durante todos los meses del año, aun cuando se llegaron a presentar enfriamientos inferiores a 10 grados centígrados bajo cero. Por lo observado, es posible concluir que los resultados han sido satisfactorios para el diseño experimental, y es posible, por tanto, intentar la construcción de invernaderos de 2000 metros cuadrados con capacidad comercial todo el año con algunas adaptaciones derivadas de una mayor superficie.
\end{abstract}

Daños agrícolas por heladas, Heladas altiplano mexicano, Invernadero subterráneo

Citation: AHUMADA-MEDINA, Albino., CHIO-AUSTRIA, Rosa María and AHUMADA-GÓMEZ, Jorge. Pilot Underground Greenhouse as an alternative against frequent and intense frosts that occur in the Altiplano Hidalguense. ECORFAN Journal-Republic of Nicaragua. 2019. 5-8: 1-5

\footnotetext{
* Correspondence to Author (email: ahumadamedina@upp.edu.mx)

$\uparrow$ Researcher contributing first author.
} 


\section{Introduction}

In its greater proportion the Mexican territory, particularly its coasts, are favourably influenced for the cultivation of vegetables by their tropical latitude, particularly in winter, when in the latitudes of the mainland the lack of light and heat become limiting factors; however, as the territory increases its height above sea level, especially regions directly exposed to the influence of cold fronts, they are exposed to the effect of frost by advection and irradiation that prevent the production of the field during the last and first part of the year. These phenomena combined with water scarcity have favoured in recent decades the development of a growing activity in agricultural production through the use of greenhouses and hydroponics in the central states of the highlands of the republic with dry-dry climates; It is also important to note that in these entities there are the best commercial opportunities facilitated by proximity and good communications with the largest national consumption centres.

In the highlands of the state of Hidalgo, the installation of greenhouses has increased in the last fifteen years, probably exceeding 40 hectares, however this data should be taken with caution, because an undetermined proportion are not in production when abandoned by various reasons among which the following stand out:

- $\quad$ Production limited to frost-free months (May-August).

Design of greenhouses with characteristics not appropriate to the climate.

- Establishment of farms with limited area.

Low level of competitiveness compared to other regions of the country with better conditions to produce vegetables throughout the year.

Lack of preparation and technical information of the producers.
For the understanding of this work, we will analyse the geographical-climatological aspects that limit agricultural production to the season that goes from May to August with 130 days free of frost, even if occasionally there are temperatures below zero in the months of May and June, without that reports of having seriously affected the economy of the producers are known.

In principle, the territory of the high plateau of Hidalgo is crossed by tropical latitudes that are around $20^{\circ}$ north but, in counterpart, in its greater proportion it maintains a height greater than 2,000 meters above sea level; It also suffers a low rainfall resulting from the mountain shadow caused by the Sierra Madre Oriental and above all it is affected from September to May by the incidence of cold fronts from the north of the continent. Together, these factors are combined to facilitate various variants of frost with potential agricultural hazard for eight, and occasionally, nine months in the year. Records obtained in the municipality of Zempoala, Hidalgo, through the Network of Meteorological Stations of the National Institute of Forest Research (NNMS) [1] and the Internal Network of Meteorological Stations of the UPP (INMSUPP) [2] between 2008 and 2014 they indicate the incidence of such events between 47 (2014) and past one hundred (2008 and 2011) table 1

\begin{tabular}{|l|r|r|r|l|l|l|l|l|r|r|r|r|r|}
\hline & $\mathbf{E}$ & $\mathbf{F}$ & $\mathbf{M}$ & $\mathbf{A}$ & $\mathbf{M}$ & $\mathbf{J}$ & $\mathbf{J}$ & $\mathbf{A}$ & $\mathbf{S}$ & $\mathbf{O}$ & $\mathbf{N}$ & $\mathbf{D}$ & Total \\
\hline 2007 & 7 & 10 & 7 & 2 & & & & & 3 & 6 & 10 & 17 & 63 \\
\hline 2008 & 26 & 8 & 9 & & & & & & 2 & 10 & 18 & 27 & 100 \\
\hline 2009 & 22 & 18 & 9 & 1 & 1 & & & & 2 & 1 & 4 & 9 & 67 \\
\hline 2010 & 9 & 7 & 6 & 1 & & & & & & 17 & 17 & 28 & 82 \\
\hline 2011 & 26 & 15 & 14 & & & & & & 3 & 12 & 8 & 24 & 102 \\
\hline 2012 & 21 & 1 & 4 & 5 & 3 & & & & & 8 & 11 & 22 & 65 \\
\hline 2013 & 10 & 18 & 10 & 1 & & & & & & 1 & 3 & 8 & 51 \\
\hline 2014 & 16 & 13 & & & 4 & & & & 4 & 5 & 5 & 47 \\
\hline
\end{tabular}

Tabla 1 Number of Monthly Frosts and Total Annuals Registered During the years 2007 to 2011

It is important to note that the severity of the damage caused by frost in agriculture is accentuated by the dates on which they occur, since the early September to October cause their damage in the final phase of the harvests and the late ones in March, April and May cause losses in the phases of crop preparation either open field or protected crops. 


\begin{tabular}{|c|r|r|r|}
\hline Date & \multicolumn{1}{|c|}{ T. Minimum } & T Maximum & T Media \\
\hline $23 / 09 / 2007$ & -0.4 & 11.42 & 11.4 \\
\hline $29 / 09 / 2008$ & -1 & 21.6 & 10.2 \\
\hline $01 / 10 / 2009$ & -4.5 & 20.6 & 8.7 \\
\hline $29 / 09 / 2010$ & -3.5 & 22.7 & 9.5 \\
\hline $08 / 09 / 2011$ & -2.6 & 19.3 & 8.0 \\
\hline $03 / 10 / 2012$ & -1.9 & 20.1 & 10 \\
\hline $30 / 11 / 2013$ & -3.7 & 21 & 8.1 \\
\hline $26 / 10 / 2014$ & -1.4 & 22.1 & 10 \\
\hline
\end{tabular}

Tabla 2 Minimum, Maximum and Average Temperatures of Days with First Frosts in the years 2007 to 2013

Table 2 shows that the first frosts can occur from the first days of September as happened on the morning of the eighth day of the mentioned month in 2011, causing innumerable losses not only in the municipality of Zempoala, Hidalgo, but its effects were felt in most of the centre of the Mexican Republic. On the other hand, the "table 3", indicates that the presence of late frosts affects during the months of April and occasionally those of May, causing significant losses those that occurred during the months of March and April where low temperatures can be interspersed with warmer days of the waste in the region, time in which the plants are more active by the stimulation of the lengthening and warmth of the days.

According to the data reported in Table 3 , in the High Valleys there were strong losses due to early frosts in September 2009 and 2006, which although there was not a markedly low decrease in temperature, if they affected the crops of field and greenhouse at harvest times; also, what happened in April 2012 and March 2013, caused losses of consideration in the vegetative material that was prepared for the following agricultural cycle.

Radiation frosts are those that are observed in the highest proportion in the highlands of Hidalgo due to the low daytime and night-time cloudiness that are frequently observed from late summer, winter and early spring, favouring the gradual cooling of the soil by losing its heat from the late hours of the afternoon, all night and early hours of dawn; However, occasionally there are advection frosts arising from the invasion of cold air masses from polar regions. These conditions may occur unexpectedly for one or several days with slightly higher or lower temperatures $0^{\circ} \mathrm{C}$.
It is important to note that the greatest losses caused by frosts in agriculture in the highlands of Hidalgo are derived from the conjugation of advection and radiation phenomena $[3,4]$. These are observed for one or several days, when a stream of air originating in Arctic latitudes, acts cooling during the day, until approximately 22: 00-24: 00 hours, reaching temperatures close to $0^{\circ} \mathrm{C}$ or lower, leaving then of running the wind for more than eight hours with the consequent loss of heat by irradiation, to present in the early hours of dawn extreme minimum temperatures for the region "table 4", as happened during the autumnwinter 2010-2011, "table 3". These extreme conditions not only tend to seriously damage outdoor or protected crops, but also affect endogenous flora of cacti and agavaceae due to the freezing of water inside plant cells.

The models of greenhouses [5,6] that have been tried in the highlands of Hidalgo, can be considered that their handling to dislodge heat during the day is efficient due to their height and ventilation systems, but they are inoperative for heat conservation and quickly they lose every night.

The proposal to build an underground greenhouse derived from the concern of taking advantage of low productivity land but well connected with large centres of consumption but adapting technologies of protected agriculture to a climate in which the types of greenhouses tested so far in Mexico do not offer satisfactory results.

\section{Material and method}

On land located at the Polytechnic University of Pachuca in the latitude of $19{ }^{\circ} 58$ '49.41" and longitude $98^{\circ} 41^{\prime}$ 07.43" and a height above sea level of 2377 meters, an excavation was carried out on clay soil of 2 meters of depth, forming a rectangle 16 meters long and 12 meters wide. Bales of barley and sacks containing clay were placed on the side walls facing northeast, with a height of 1.5 meters on the side walls, bales and sacks were also placed but gradually decreasing until reaching the level of the two meters on the southwest wall. All the walls were covered in their lower portion with earth to give greater protection against lateral winds. 
The excavation was covered with polyethylene fabric with a shadow capacity of $30 \%$ and a $50 \%$ half shade mesh was placed on it. On these two permanent covers, a third plastic cloth was placed that unwinds only when frosty nights are expected, to form an air mattress that does not allow heat to escape.

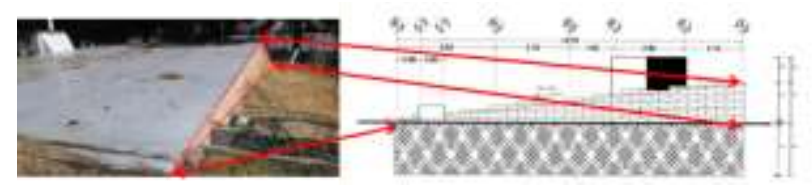

Figure 1 Side view of underground greenhouse

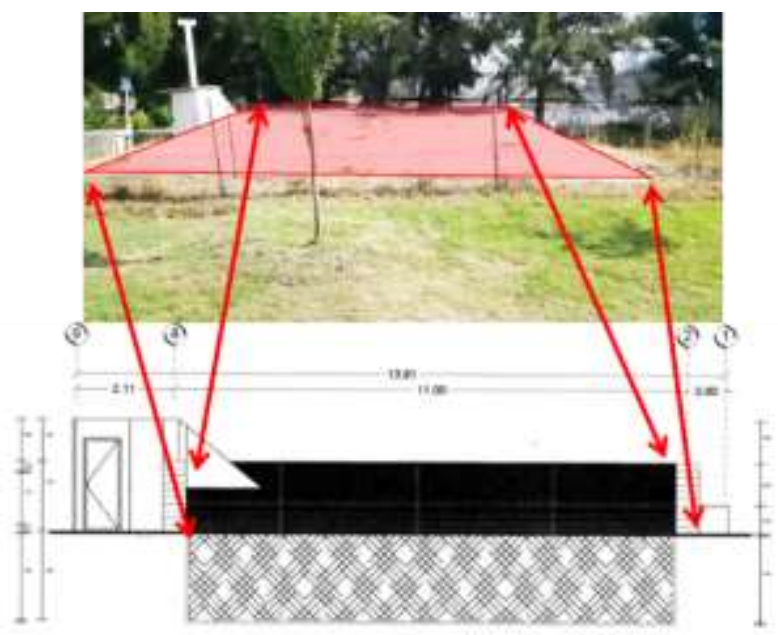

Figure 2 Front view of underground greenhouse

Temperature monitoring is done every 30 minutes by comparing three different weather stations (WSUPP):

- Station 1. It is located outdoors and indicates the general weather conditions. Davis Vantage Pro 2 Plus 06162.

Station 2. It is located in a tunnel greenhouse of $5 \mathrm{~m}$ high, with an area of 180 square meters, indicating the temperature and humidity. Wireless Temperature / Humidity 06382. Davis.

Station 3. It is located in the underground experimental greenhouse, indicating the temperature and humidity. Wireless Temperature / Humidity 06382. Davis.

The information of the three stations is concentrated in the console that is part of the Vantage Pro 2 Plus station and through the intercom that allows the Weather Link 06510SER software. Davis, the information has been concentrated for interpretation on a PC.

\section{Results}

The Polytechnic University of Pachuca has several types of greenhouses, so it is possible to make comparative measurements in real time in them with respect to the time in the open field.

In these observations it has been established that although during the day the greenhouses with polyethylene walls fulfil their function of capturing and accumulating the infrared energy, during the last hours of the day, they lose it quickly and throughout the night, until dawn internal and external temperatures are maintained with little difference, in the case that the low temperatures are prolonged longer in the first hours after dawn, inside the installation due to the ice formed on the internal walls it defrosts more slowly than in the Exterior.

In table 5, the evolution of an irradiation frost can be observed that although it starts at 6:00 am, the difference between the outside and inside temperatures of the greenhouse with polyethylene walls, while the underground greenhouse starts the weather phenomenon with a positive difference of 7.5 degrees Celsius and maintains this trend throughout the event throughout the event.

Regarding the behaviour of temperatures during the rigor of an advection cooling linked to a table 6 irradiation, the underground greenhouse showed an appropriate behaviour, which although it reached temperatures below $0^{\circ}$, these can be considered manageable at a minimum cost, either with passive preventive methods or through the use of heaters since the earth walls do not lose heat quickly and the ceiling being low can be managed so that it does not dissipate heat. In the reported case, no precautions of any kind were taken.

For the damping of temperatures during the day, it has been experimented with various types of heat extractors, being the installation of side curtains in the upper part of the greenhouse the best means achieved to keep the excess temperature controlled during the hours of greatest solar incidence. 


\section{Conclusions}

As for crops, the underground greenhouse has been worked as of January 2012 with various types of vegetables that have generally been adapted, mainly tomatoes and other medicinal plants useful in experiments that are developed by professors and students of the Bachelor of Physical Therapy, that if it were not for the protection of the greenhouse, they would not have resisted the effect of the frost observed during the last three years.

The integral operation of the greenhouse in its pilot stage allows us to conclude that its scaling to protected areas of 2000 square meters is possible, so that its operation is programmable and commercially attractive to produce according to the market's own demands and make better use to lands that are currently used for the production of barley and oats, although they show resistance to the eventualities of the climate and short cycles for their cultivation, the value of their crops in the market is unsatisfactory and they can also be affected by droughts and early frost.

\section{Acknowledgments}

Universidad Politécnica de Pachuca

Dr. Marco Antonio Flores González

Dr. Francisco Rafael Trejo Macotela

Dr. Alejandro Téllez Jurado

\section{References}

[1].

http://clima.inifap.gob.mx/redinifap/est.aspx? est $=27783$. 2009-2014

[2]. RIEMUPP. 2012-2016. Tecnologías Intermedias. Universidad Politécnica de Pachuca.

[3,4]. Olcina Cantos J. Riesgos Climáticos en La Península Ibérica. Libros Penthalon. Madrid, 1994. 440 pp.

Snyder L. R. Protección contra las heladas: fundamentos,práctica y economía. FAO. Serie Sobre el Medio Ambiente y la Gestión de Recursos. Vol. 1. Roma 2010.

[5]. Urrestarazu Gavilán. Ediciones Mundi Prensa.Madrid-Barcelona México
[6]. Castañeda-Miranda R. Análisis y simulación del Modelo Físico de un Invernadero Bajo Condiciones Climáticas de la Región Central de México. Agrociencia 41: 317-335. 2007. 